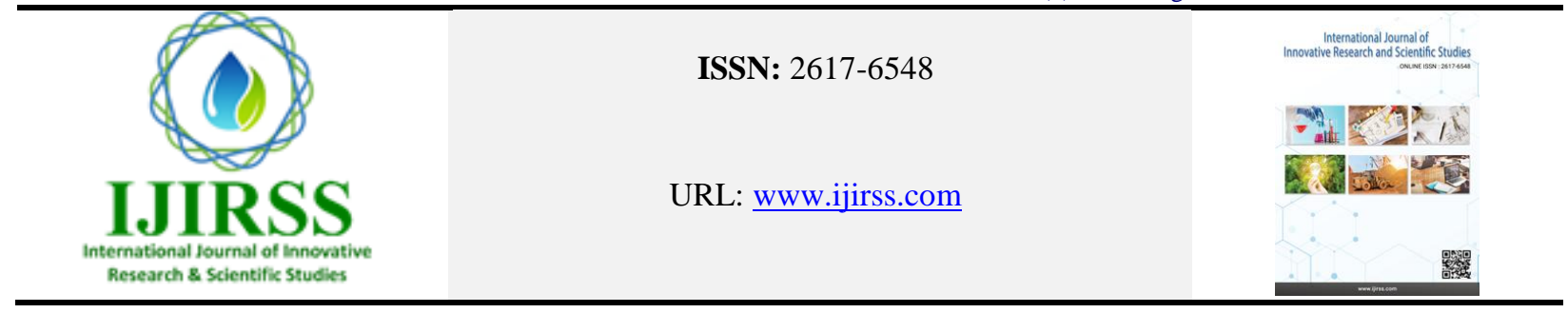

\title{
Effect of Temperature on Bio-Oil Fractions of Palm Kernel Shell Thermal Distillation
}

\author{
Deana Qarizada*1,2, Erfan Mohammadian ${ }^{1}$, Azil Bahari Alias ${ }^{1}$, Humapar Azhar Rahimi ${ }^{3,4}$, Suriatie Binti Mat Yusuf ${ }^{1}$
}

${ }^{1}$ Faculty of Chemical Engineering (FKK), Universiti Technology MARA, 40450 Shah Alam, Selangor, Malaysia

${ }^{2}$ Faculty of Chemical Engineering, Jawzjan University, Jawzjan, Afghanistan

${ }^{3}$ Faculty of Education, Jawzjan University, Jawzjan, Afghanistan

${ }^{4}$ Faculty of Education, Shaheed Prof, Rabbani University, Kabul Afghanistan

*Corresponding author: Deana Qarizada (deana.qarizada11@gmail.com)

\begin{abstract}
Distillation is an essential thermo chemical process; it mainly depends on temperature which affects mostly the product yield and composition. The aim of this research is to investigate the effect of temperature on the characterization of bio-oil liquid fraction derived from palm kernel shell (PKS) bio-oil. The temperatures were $100{ }^{\circ} \mathrm{C}$ and $140^{\circ} \mathrm{C}$. The higher heating value (HHV) obtained were $28.6 \mathrm{MJ} / \mathrm{Kg}$ and $31.5 \mathrm{MJ} / \mathrm{Kg}$ for bio-oil fraction $100^{\circ} \mathrm{C}$ and $140^{\circ} \mathrm{C}$ respectively. The GC- $\mathrm{MS}$ analysis determined that phenol is the dominant product in bio-oil fractions.
\end{abstract}

Keywords: Fast pyrolysis, thermal distillation, palm kernel shell, biomass, bio-fuel.

DOI: 10.53894 /ijirss.v1i2.7

Funding: Authors would like to thank faculty of chemical engineering (FKK), and Research management institute (RMI) in UiTM for providing funds (600-RMI/DANA 5/3/BESTARI0008/2016) that made this research possible.

History: Received: 27 March 2018/Revised: 6 April 2018/Accepted: 16 April 2018/Published: 14 October 2018

Licensed: This work is licensed under a Creative Commons Attribution 4.0 License $(\mathrm{coc}) \mathrm{EY}$

Acknowledgement: All authors contributed to the conception and design of the study.

Competing Interests: The authors declare that they have no conflict of interests.

Transparency: The authors confirm that the manuscript is an honest, accurate, and transparent account of the study was reported; that no vital features of the study have been omitted; and that any discrepancies from the study as planned have been explained.

Ethical: This study follows all ethical practices during writing.

\section{Introduction}

In today's world, almost $81 \%$ of the total transportation fuels are prepared by petroleum. The depletion of natural resources (non-renewable sources) is an important issue and attention needs to be paid to it. The air contamination is a wide problem in the world also and it is formed from the internal combustion of fuel that produces greenhouse gases such as $\mathrm{CO}$ and $\mathrm{SO}_{2}$ stable released to the environment. Biomass is an alternative energy source for crude oil. Biomass commutation to bio-oil comprises two processes; flash pyrolysis and hydrothermal liquefaction. The main challenges are the low product, negligible bio-oil quality and the value of bio-oil commutation from biomass [1]. Biomass is an accessible, low-value and renewable reserve, which has received consideration due to its multiple characteristics. It is a renewable energy that can be changed into bio-fuel by different methods such as pyrolysis, gasification, combustion, and liquefaction. These methods are conventional and the disadvantages of these methods are higher temperature, long processing time, and usage of catalysts $[2,3]$. Fast pyrolysis using palm kernel shell (PKS) is one of the methods that can improve the properties of the biomass to the next level of advancement. The pyrolysis is conducted at a temperature of about $500^{\circ} \mathrm{C}$ with vapor residence of 30 minutes. The pyrolysis feedstock used wood, waste, empty fruit bunch (EFB), and PKS, with a bio-oil yield of 70\%, and 
char and gas at around 15\%, each [4]. Pyrolysis is dependent on the thermo chemical process. Bio-oil is a liquid fuel that burns in diesel engines or boilers and it is of high density and oxygenated liquid [5]. Therefore, bio-oil from fast pyrolysis application as fuels or sources of chemical feed stock requires some form of thermo distillation to improve storage stability and heating value [6]. Thermo distillation of fast pyrolysis bio-oil can be a good enhanced process. However, oxygenated components can polymerize. In conventional distillation, relatively high temperature is necessary [6]. Bio-oil is a product of fast pyrolysis obtained by means of distillation. The experiment operates at a temperature of $100 \mathrm{oC}, 140 \mathrm{oC}$ and residual pressure of $15 \mathrm{mmHg}$. The distillation of bio-oil has low oxygen content, about $9.2 \mathrm{wt} \%$ than fast pyrolysis' product and the bio-oil produced from distillation has lower corrosively but higher heating value and stability. After distillation, the bio-oil heating value becomes higher, that is $34.2 \mathrm{MJ} / \mathrm{kg}$, and the value is twice higher than that of a fast pyrolysis [7].

PKS is the waste; it is obtained after the production of palm oil from the broken nuts. The kernels are removed with the shell essentially left as waste. PKS has different shapes and sizes, and the hard, stony shell is covered by the kernel. The shell compounds are made of $33 \%$ charcoal, $45 \%$ pyroligneous liquor and $21 \%$ combustible gas as reported [8]. PKS has higher calorific value, lower sulfur content and can be found easily. The bio-oil which was produced from PKS and also distilled bio-oil fraction was characterized in terms of physical and chemical properties Therefore, to reduce the instant fossil fuel greenhouse gases, the conventional fuel needs to be replaced with organic crude fuels (unconventional fuels). To reduce the instant fossil fuel greenhouse gases, the conventional fuel needs to be replaced with organic crude fuels (unconventional fuels) [9]. Hence, the aim of this study is to investigate the effect of temperature on bio-oil fractions of palm kernel shell thermal distillation to find alternative fossil fuel. Distillation is a suitable method to improve the bio-oil of fast pyrolysis. Oxygenated components can polymerize with this method. In conventional distillation process high temperature is necessary. Therefore, thermal distillation of fast pyrolysis of bio-oil is performed to improve the storage, stability, and heating value of fast pyrolysis bio-oil [6].

\section{Materials and Methods}

\subsection{Feedstock and Chemicals}

The raw material used in this research is palm kernel shell that was collected from a palm oil mill industry located in Klang, Selangor, Malaysia. The nitrogen gas was supplied by the UiTM laboratory and was used in the pyrolysis process. The particle size of PKS was $10-30 \mathrm{~mm}$. The bulk density was around $560 \mathrm{~kg} / \mathrm{m} 3$. As shown in Figure 1 . The moisture content obtained from the sundried PKS was around $12 \mathrm{wt} \%$. The major weight loss is different for EFB (57 wt $\%$ ) and PKS (52 wt \%), whereby they are both lower than sawdust's weight loss (67wt\%) [10].

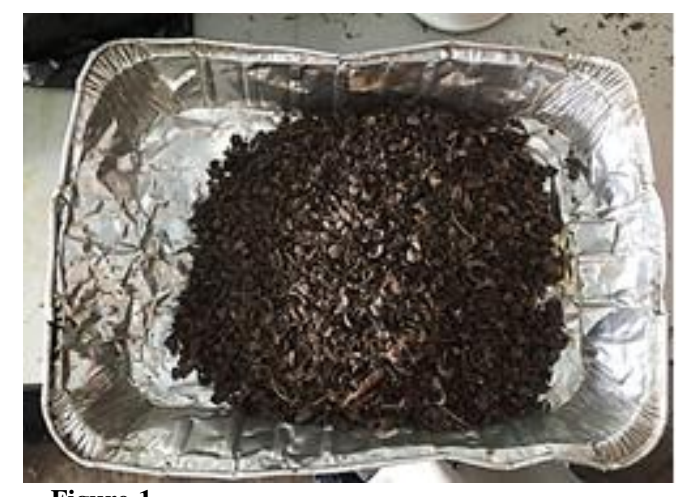

Figure-1.

Raw material PKS.

The bio-oil chemical and physical properties primarily depend on chemical and physical properties of the raw material as well as reaction conditions of pyrolysis. The physical and chemical properties of PKS were provided with proximate and ultimate analysis. Table 1 shows the chemical and physical properties of PKS. The PKS particle size was between 10-30 $\mathrm{mm}$, the bulk density of PKS was $560 \mathrm{Kg} \mathrm{m}-3$, while the PKS moisture content was 12 wt. \%. The proximate analysis of PKS showed the percentage of the volatile fraction, fixed carbon and ash content, were recorded at $52 \mathrm{wt} \%, 24 \mathrm{wt} \%$ and, $16 \mathrm{wt} \%$ respectively. In addition, the ultimate analysis of PKS provided the hydrogen, oxygen and carbon content, that were $5.4 \mathrm{wt} \%, 44.8 \mathrm{wt} \%$ and, $49.8 \mathrm{wt} \%$, respectively.

\subsection{Procedure of Bio-Oil Production}

The bio-oil production has been pyrolyzed in UiTM's laboratory scaled fixed bed reactor. The reactor was positioned in vertically and it made of stainless steel with the size of $10 \mathrm{~cm}$ i.d and $50 \mathrm{~cm}$ height. Around $2 \mathrm{~kg}$ of the biomass was the feedstock, placed in a batch reactor. The nitrogen gas was injected a mount $200 \mathrm{ml} / \mathrm{min}$ inside the reactor from the bottom to replace the air from the reactor with the gases formed from the pyrolysis of the biomass inside the reactor. There were two condensers the first condenser was cooled using dry ice, which was the vapor temperature reduced to around $60^{\circ} \mathrm{C}$, and the second condenser was cooled by the circulation of ice water, the temperature reduced around $5^{\circ} \mathrm{C}[10]$. 
Table-1.

Chemical and physical Characterization of PKS

\begin{tabular}{c|l}
\hline Properties & PKS \\
\hline Particle size $(\mathrm{mm})$ & $10-30$ \\
\hline Bulk density $\left(\mathrm{Kgm}^{-3}\right)$ & 560 \\
\hline Moisture content $(\mathrm{wt} \%)$ & 10 \\
\hline Calorific Value $(\mathrm{KJ} / \mathrm{KG})$ & 17.092 \\
\hline Proximate analysis $(\mathbf{w t} \%$, dry basis & \\
\hline Volatile fraction & 52 \\
\hline Fixed carbon & 24 \\
\hline Ash content & 16 \\
\hline Ultimate analysis(wt\%, dry basis) & \\
\hline $\mathrm{C}$ & 49.8 \\
\hline $\mathrm{H}$ & 5.4 \\
\hline $\mathrm{O}$ & 44.8 \\
\hline
\end{tabular}

\subsection{Distillation of Bio-Oil Procedure}

The method used to upgrade the bio-oil is via a reactor and stirring hotplate that will assist the distillation process through some modifications made. Firstly, the bio-oil placed inside the reactor and heated at about $100^{\circ} \mathrm{C}$ with stirring hotplate. Finally, 10 fractions were collected.

\subsection{Analytical Methods}

The physical characteristic of bio-oil and bio-oil fractions was determined including the $\mathrm{PH}$ value, higher heating value, moisture content, density, and ultimate analysis. Densities of bio-oil and bio-oil fraction were measured at $25^{\circ} \mathrm{C} \mathrm{by}$ using the hydrometer. The $\mathrm{pH}$ of bio-oil and bio oil fractions was measured by digital $\mathrm{PH}$ meter Toledo ${ }^{\mathrm{TM}}$. The higher heating value was estimated via bomb calorimeter. The bio oil and bio oil water content were measured by water analyzer (satorius ${ }^{\text {TM }}$ Model- MA35). All the analysis is shown in Table 3. The bio-oil and bio-oil fractions functional groups determined by FT- IR spectroscopy. The FTIR spectra of bio-oil and fraction of bio-oil utilized perkin-Elmer Spectrum GX FT- IR spectrometry, and the wave number were between 4000- $400 \mathrm{~cm}-1$. At 4-1spectrl resolution fifty scans were recorded [11]. The Gas chromatography- mass spectroscopy (GCMS) analysis of bio-oil fractions as has shown in Table 2. Phenol and its derivative were the highest values of the peak areas of possible compounds. The condensation of phenol and its subsidiary were found very high which demonstrate the appropriateness of the oil to be observed for value-added chemical [12].

\section{Results and Discussion}

The chemical and physical characteristics of feedstock play an important role in the yield properties. Therefore, the PKS raw material bio-oil and bio-oil fraction were characterized to know the chemical composition and physical properties, as shown in Table1 and 3 .First, the biomass has around 50wt\% moisture; however, after drying in the dryer for 48 hours, it is reduced around $20 \mathrm{wt} \%$, for the biomass and $10 \mathrm{wt} \%$ for the bio-oil respectively.

The bio-oil fractions have higher water content it is due to the high moisture content of the feedstock. Surface area and particle size play an important role on the yield content. Thus, the particle size was $8-12 \mathrm{~mm}$ it crushed with grinding machine [13]. The calorific value of bio-oil was $20-21 \mathrm{MJ} / \mathrm{Kg}$ [14]. The bio-oil density was $1.04 \mathrm{~g} / \mathrm{mL}$ at $25^{\circ} \mathrm{C}$. The bio-oil fractions $\mathrm{pH}$ were between 2.52- 2.67. The bio oil fractions densities were $298 \mathrm{wt} \%$ and $994.56 \mathrm{wt} \%$. The HHV of bio oil fractions were for $\mathrm{PKS} 100^{\circ} \mathrm{C}$ around $28.6 \mathrm{MJ} / \mathrm{Kg}$ and for $\mathrm{PKS} 140^{\circ} \mathrm{C}$ was around $31.5 \mathrm{MJ} / \mathrm{Kg}$. The bio-oil fractions energy content were more than half of the diesel energy content $43.09 \mathrm{MJ} / \mathrm{Kg}$, it is still a considerable amount of energy.

\subsection{Chemical Analysis of Bio-Oil and Bio-Oil Fraction}

The FTIR spectroscopy PKS bio-oil as shown in Figure 2 indicates that the bio-oil consisted oxygenated organic compounds. The broad bond between $3360-3600 \mathrm{~cm}-1$ indicates the $\mathrm{O}-\mathrm{H}$ stretching vibration proves the presence of phenol and alcohol. The $\mathrm{C}=\mathrm{O}$ stretching vibration between $1699-1710 \mathrm{~cm}-1$ indicated the presence of the conjugated aldehyde. The stretching vibration between $1637-1650 \mathrm{~cm}-1$ indicated the presence of an aromatic group. The $\mathrm{C}=\mathrm{C}$ stretching vibration between $1501-1510 \mathrm{~cm}-1$ indicated the presence of which indicated the presence of alkenes. The C-O, C-C stretching vibration between 1474- $1475 \mathrm{~cm}-1$ indicated the presence of Alkanes, alcohol, phenols, ethers and lipids [15, 16]. The $\mathrm{C}=\mathrm{C}$ stretching vibration between $1379-1450 \mathrm{~cm}-1$ which indicated the presence of mono and polycyclic substituted aromatic group [17]. The C-O stretching vibration between 1263- $1300 \mathrm{~cm}-1$ which indicated the presence of alcohol [18]. The C-O stretching vibration between 1015 and $1200 \mathrm{~cm}-1$ which indicated the presence of carbonyl component [16]. 


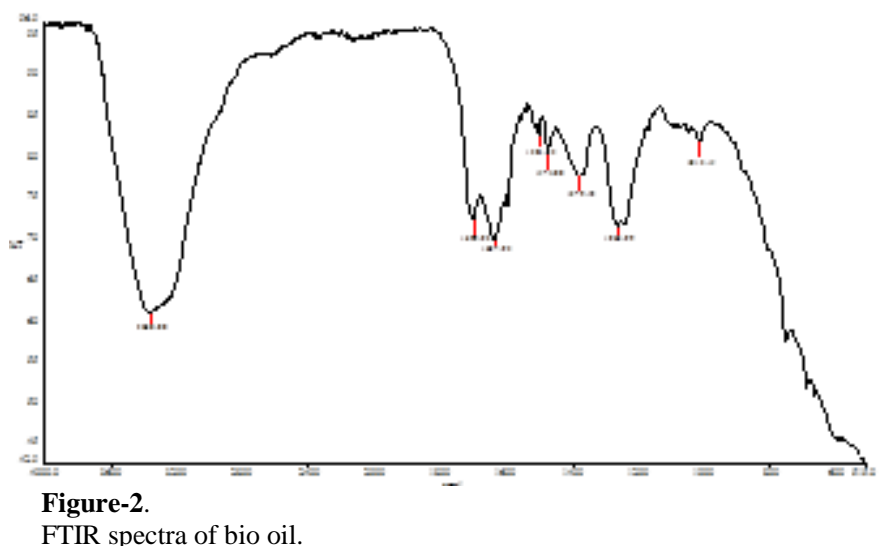

GCMS analysis was carried out with typical bio-oil fractions and determined type of possible compounds and nature in the bio-oil fractions. The bio-oil fractions possible compounds were identified by the MS search libraries.

The possible compounds of bio-oil fractions are listed in Table 2. GCMS analysis result shows that the Phenol derivative is the major group of compounds existed in bio-oil fractions. Most of the compounds were oxygenated compounds.

Table-2.

Possible Chemical Compounds of bio-oil fractions according to the GC-MS Analysis.

\begin{tabular}{l|l|l}
\hline Possible Chemical compounds & $\begin{array}{l}\text { Molecular } \\
\text { formula }\end{array}$ & $\begin{array}{l}\text { Area, } \\
\text { \% }\end{array}$ \\
\hline & & \\
\hline Furfuryl hexanoate & $\mathrm{C}_{11} \mathrm{H}_{16} \mathrm{O}_{3}$ & 4.31 \\
\hline Idazoxan & $\mathrm{C}_{11} \mathrm{H}_{12} \mathrm{~N}_{2} \mathrm{O}_{2}$ & 2.12 \\
\hline 1-(Trimethylsilyl)-1-propyne & $\mathrm{C}_{6} \mathrm{H}_{2} \mathrm{Si}$ & 2.12 \\
\hline 4-Picoline & $\mathrm{C}_{6} \mathrm{H}_{7} \mathrm{~N}$ & 9.83 \\
\hline Idazoxan & $\mathrm{C}_{11} \mathrm{H}_{12} \mathrm{~N}_{2} \mathrm{O}_{2}$ & 9.83 \\
\hline Benzene,(1,1dimethylethoxy) & $\mathrm{C}_{12} \mathrm{H}_{16} \mathrm{O}$ & 9.83 \\
\hline Phenol, 4-methyl & $\mathrm{C}_{7} \mathrm{H}_{8} \mathrm{O}$ & 1.42 \\
\hline $\begin{array}{l}\text { 1,4:3,6-Dianhydro-à-d- } \\
\text { glucopyranose }\end{array}$ & $\mathrm{C}_{6} \mathrm{H}_{8} \mathrm{O}_{4}$ & 9.54 \\
\hline 1,4-Benzenediol, 2-methoxy & $\mathrm{C}_{7} \mathrm{H}_{8} \mathrm{O}_{3}$ & 8.17 \\
\hline Phenol, 3-nitro & $\mathrm{C}_{6} \mathrm{H}_{5} \mathrm{NO}_{3}$ & 2.91 \\
\hline $\begin{array}{l}\text { Propan-2-one,1-(4-isopropoxy-3- } \\
\text { methoxyphenyl) }\end{array}$ & $\mathrm{C}_{13} \mathrm{H}_{18} \mathrm{O}_{3}$ & 1.05 \\
\hline Dodecanoic acid, isooctyl ester & $\mathrm{C}_{20} \mathrm{H}_{40} \mathrm{O}_{2}$ & 6.81 \\
\hline Dodecanoic acid & $\mathrm{C}_{12} \mathrm{H}_{24} \mathrm{O}_{2}$ & 6.81 \\
\hline
\end{tabular}

Table-3.

Properties of bio-oil and bio-oil fractions

\begin{tabular}{|c|c|c|c|c|c|c|}
\hline \multirow[b]{2}{*}{ properties } & \multicolumn{4}{|c|}{ Bio-oil fractions } & \multicolumn{2}{|l|}{ Bio-oils } \\
\hline & $\begin{array}{l}\text { PKS - } \\
100\end{array}$ & $\begin{array}{l}\text { PKS - } \\
140\end{array}$ & $\begin{array}{l}\text { EFB - } \\
100\end{array}$ & $\begin{array}{l}\text { EFB - } \\
140\end{array}$ & PKS & EFB \\
\hline $\begin{array}{l}\text { Moisture content } \\
(w t \%)\end{array}$ & 21.35 & 13 & 23.82 & 18.47 & $40-60$ & $30-40$ \\
\hline PH & 2.67 & 2.52 & 3.12 & 2.95 & 3.5 & 3 \\
\hline Density (wt\%) & 982 & 994.56 & 994.56 & 970.59 & 1040 & 1040 \\
\hline \multicolumn{7}{|l|}{ Elemental analysis } \\
\hline C & 56.3 & 64.63 & 56.7 & 60.2 & $40-50$ & $40-45$ \\
\hline H & 7.2 & 7.3 & 6.89 & 7.1 & $5.0-6.0$ & $4.0-5.0$ \\
\hline $\mathbf{O}$ & 36.18 & 27.81 & 36.16 & 32.45 & $40-50$ & $45-50$ \\
\hline $\mathbf{N}$ & 0.19 & 0.15 & 0.11 & 0.11 & $\begin{array}{ll}0- & 0.2 \\
\end{array}$ & 0.02 \\
\hline $\mathbf{S}$ & 0.13 & 0.11 & 0.14 & 0.14 & $<0.001$ & $<0.001$ \\
\hline HHV & 28.6 & 31.5 & 22.7 & 25.4 & 16.74 & 17.09 \\
\hline
\end{tabular}


Oxygenated compounds decrease the HHV and also decrease the quality of bio-oil and bio-oil fractions to be used as fuel utilization and transportation. However, the oxygenated compounds reduce is still possible. These components need some methods to reduce the oxygenated compounds such as hydro treating and hydro cracking.

\section{Conclusions}

PKS bio-oil fraction was produced from thermal distillation at $100^{\circ} \mathrm{C}$ and $140^{\circ} \mathrm{C}$. The higher heating value of bio-oil fractions determine by bomb calorimeter. The bio-oil fraction component in $140^{\circ} \mathrm{C}$ compared with bio-oil fraction in $100^{\circ} \mathrm{C}$. The component fraction in $140^{\circ} \mathrm{C}$ was perfectly ignited. The $\mathrm{PKS}$ bio-oil in $140^{\circ} \mathrm{C}$ will be considered as bio-oil to be used in the future.

\section{References}

[1] S. Xiu and A. Shahbazi, "Bio-oil production and upgrading research: A review, renew," Sustain Energy Rev, vol. 16, pp. 44064414, 2012.Available at: https://doi.org/10.1016/j.rser.2012.04.028.

[2] R. C. Veses, Z. Shah, P. M. Kuamoto, E. B. Caramão, M. E. Machado, and R. Silva, "Fundamentals of renewable energy and applications bio-oil production by thermal cracking in the presence of hydrogen," vol. 6, pp. 1-7, 2015.Available at: https://doi.org/10.4172/2090-4541.1000194.

[3] N. Laksmono, M. Paraschiv, K. Loubar, and M. Tazerout, "Biodiesel production from biomass gasification tar via thermal/catalytic cracking," Fuel Process. Technol, vol. 106, pp. 776-783, 2013.Available at: https://doi.org/10.1016/j.fuproc.2012.10.016.

[4] N. Abdullah, F. Sulaiman, and H. Gerhauser, "Characterisation of oil palm empty fruit bunches for fuel application," Journal of Physical Science, vol. 22, pp. 1-24, 2011.

[5] N. Abdullah, H. Gerhauser, and A. V. Bridgwater, "Bio-oil from fast pyrolysis of oil palm empty fruit bunches," Journal of Physical Science, vol. 18, pp. 57-74, 2007.

[6] J. Zheng and Q. Wei, "Improving the quality of fast pyrolysis bio-oil by reduced pressure distillation," Biomass and Bioenergy, vol. 35, pp. 1804-1810., 2011.

[7] J. Kuberan and N. Alagumurthi, "Improving the quality of fast pyrolysis algae bio-oil by distillation," vol. 9, pp. 3479-3482, 2016.

[8] C. Nwaobakata and J. C. Agunwamba, "Effect of palm kernel shells ash as filler on the mechanical properties of hot mix asphalt," vol. 6, pp. 42-49, 2014.

[9] F. Abnisa, A. Arami-niya, W. M. A. W. Daud, J. N. Sahu, and M. INoor, "Utilization of oil palm tree residues to produce biooil and bio-char via pyrolysis," Energy Convers. Manag, vol. 76, pp. 1073-1082, 2013.Available at: https://doi.org/10.1016/j.enconman.2013.08.038.

[10] N. Suhada, A. Rasid, and M. Asadullah, "Effect of temperature on product yields and characteristics of palm kernel shell fast pyrolysis," 2014.

[11] M. Asadullah, M. A. Rahman, M. M. Ali, M. Rahman, M. Motin, M. Sultan, and M. Alam, "Production of bio-oil from fixed bed pyrolysis of bagasse," Fuel, vol. 86, pp. 2514-2520, 2007.Available at: https://doi.org/10.1016/j.fuel.2007.02.007.

[12] M. Engineering, vol. 7, pp. 1134-1140, 2014.

[13] M. A. Sukiran, N. O. R. Kartini, A. B. U. Bakar, and C. M. E. E. Chin, "Optimization of pyrolysis of oil palm empty fruit bunches optimization of pyrolysis of oil palm empty fruit bunches, am," vol. 21, pp. 653-658, 2009.Available at: Journal of Applied Sciences.

[14] M. A. Sukiran, N. O. R. Kartini, A. B. U. Bakar, and C. M. E. E. Chin, "Optimization of pyrolysis of oil palm empty fruit bunches," Journal of Oil Palm Research, vol. 21, pp. 653-658, 2009.

[15] S. Ceylan and J. L. Goldfarb, "Green tide to green fuels: TG-FTIR analysis and kinetic study of Ulva prolifera pyrolysis," Energy Convers. Manag, vol. 101, pp. 263-270, 2015.Available at: https://doi.org/10.1016/j.enconman.2015.05.029.

[16] M. A. Sukiran, S. K. Loh, and N. A. Bakar, "Production of bio-oil from fast pyrolysis of oil palm biomass using fluidised bed reactor," vol. 6, pp. 52-62, 2016.

[17] M. Asadullah, N. S. Ab Rasid, S. A. S. A. Kadir, and A. Azdarpour, "Production and detailed characterization of bio-oil from fast pyrolysis of palm kernel shell," Biomass and Bioenergy, vol. 59, pp. 316-324, 2013.Available at: https://doi.org/10.1016/j.biombioe.2013.08.037.

[18] N. Abdullah, F. Sulaiman, and H. Gerhauser, "Characterisation of oil palm empty fruit bunches for fuel application," Journal of Physical Science, vol. 22, pp. 1-24, 2011. 